\title{
AGRICULTURAL ENTREPRENEURSHIP OF AKMOLA REGION OF KAZAKHSTAN ON THE BACKGROUND OF PANDEMIC
}

\author{
ПАНДЕМИЯ КЕЗІНДЕГІ ҚАЗАҚСТАННЫН АҚМОЛА ОБЛЫСЫНЫН \\ АГРАРЛЫҚ КӘСІПКЕРЛІГІ
}

\section{АГРАРНОЕ ПРЕДПРИНИМАТЕЛЬСТВО АКМОЛИНСКОЙ ОБЛАСТИ КАЗАХСТАНА НА ФОНЕ ПАНДЕМИИ}

\author{
M.B. KUANDYKOVA ${ }^{1 *}$ \\ Ph.D student \\ L.A. OMARBAKIYEV ${ }^{1}$ \\ D.E.SC., Professor \\ M. KAMYSBAYEV ${ }^{2}$ \\ D.E.Sc., Professor \\ ${ }^{1}$ «Turan» University, Almaty, Kazakhstan \\ ${ }^{2}$ International University of Information Technologies, Almaty, Kazakhstan \\ *corresponding author e-mail: marchan1402@mail.ru \\ М.Б. ҚУАНДЫҚОВА ${ }^{1 *}$ \\ Ph.D докторанты \\ Л.А. ОМАРБАКИЕВ ${ }^{1}$ \\ э.Ғ.Ә., профрессор \\ М. КАМЫСБАЕВ \\ Э.Ғ.Ә., профрессор \\ ${ }^{1}$ «Туран» университеті, Алматы, Қазақстан \\ ${ }^{2}$ Халықаралық ақпараттық технологиялар университеті, Алматы, Қазақстан \\ *автордың электрондық поштасы: marchan1402@mail.ru \\ М.Б. КУАНДЫКОВА ${ }^{1 *}$ \\ докторант Ph.D \\ Л.А. ОМАРБАКИЕВ ${ }^{1}$ \\ Ә.э.Н., профрессор \\ М.К. КАМЫСБАЕВ ${ }^{2}$ \\ Ә.э.н., профрессор \\ ${ }^{1}$ Университет «Туран», Алматы, Казахстан \\ ${ }^{2}$ Международный университет информационных технологий, Алматы, Казахстан \\ *электронная почта автора: marchan1402@mail.ru
}

Abstract. The aim of the study is to study the state of agricultural entrepreneurship in Akmola region of Kazakhstan in the context of the coronavirus pandemic. Objectives - to identify its consequences for agriculture in the region. Results - the ways of combating them, measures of public support of enterprises for sustainable development of the republic's economy are shown. The Covid-19 pandemic has affected agricultural sector, forcing States to close borders. There are also food shortages in other countries such as Europe and North America, as well as a shortage of specialists caused by the emergence of new barriers to cheap labor on farms. Based on the use of economic and statistical method, the data of indicators "The share of gross value added of small and medium-sized businesses in the GRP of the regions of Kazakhstan" for Akmola region for 2019-2020, the structure of operating small and medium-sized agribusiness entities, exports and imports in trade with all States are presented. Based on the analysis, a steady growth was noted in the field of agro-industrial production of Akmola region. The pandemic has affected different sectors of economy in different ways. With regard to food - essential goods, such strict restrictions have not been introduced. According to statistics, for the six months of 2021, agricultural production increased by $2.4 \%$ compared to the same period last year. Conclusions - as a result of the research, it was determined that in Akmola region the growth of agricultural enter- 

prises was about $13 \%$. This is the highest figure in the last 10 years. During the crisis, agroindustrial complex has become the main factor holding back inflation.

Аңдатпа. Зерттеудің мақсаты - "коронавирус" пандемиясы жағдайында Қазақстанның Ақмола облысындағы ауыл шаруашылығы кәсіпкерлігінің жағдайын зерттеу. Міндеттері осы аймақтың ауыл шаруашылығы үшін оның салдарын анықтау. Нәтижелер - оларға қарсы күрес жолдары, республика экономикасының тұрақты дамуы үшін кәсіпорындарды мемлекеттік қолдау шаралары көрсетілген. Covid-19 пандемиясы аграрлық секторға әсер етіп, мемлекеттерді шекараны жабуға міндеттеді. Еуропа мен Солтүстік Америка сияқты басқа елдерде де азық-түлік тапшылығы, сондай-ақ фермаларда арзан жұмыс күшіне жаңа кедергілердің пайда болуынан туындаған мамандардың жетіспеушілігі байқалады. Экономикалықстатистикалық әдісті қолдану негізінде Ақмола облысы бойынша 2019-2020 жылдарға арналған "Қазақстан өңірлерінің ЖөӨ-дегі шағын және орта кәсіпкерліктің жалпы қосылған құнының үлесі" көрсеткіштерінің деректері, агробизнестің жұмыс істеп тұрған шағын және орта субъектілерінің, барлық мемлекеттермен саудадағы экспорт пен импорттың құрылымы келтірілген. Талдау негізінде Ақмола өңірінің агроөнеркәсіптік өндірісі саласында тұрақты өсім байқалады. Пандемия экономиканың әртүрлі салаларына әр түрлі әсер еткен. Азық- түлік өнімдеріне - бірінші кезекте қажет тауарларға қатысты мұндай қатаң шектеулер енгізілген жоқ. Статистика деректері бойынша 2021 жылдың алты айында ауыл шаруашылығы өнімінің көлемі өткен жылдың сәйкес кезеңімен салыстырғанда 2,4\%-ға өскен. Қорытындылар - жүргізілген зерттеулер нәтижесінде Ақмола облысында АӨК кәсіпорындарының өсімі шамамен 13\%-ды құрағаны анықталған. Бұл - соңғы он жылдағы ең жоғары көрсеткіш. Агроөнеркәсіптік кешені дағдарыс жағдайында инфляцияны тежейтін негізгі факторға айналған.

Аннотация. Цель исследования - изучение состояния сельскохозяйственного предпринимательства в Акмолинской области Казахстана в условиях пандемии «коронавирус». Задачи - выявление ее последствий для сельского хозяйства данного региона. Результаты показаны пути борьбы с ними, меры государственной поддержки предприятий для устойчивого развития экономики республики. Пандемия Covid-19 затронула аграрный сектор, обязывая государства закрывать границы. Наблюдается дефицит продовольствия также и в других странах, таких как Европа и Северная Америка, а также нехватка специалистов, вызванная появлением новых барьеров для дешевой рабочей силы на фермах. По итогам применения экономико-статистического метода приведены данные показателей «Доля валовой добавленной стоимости малого и среднего предпринимательства в ВРП регионов Казахстана» по Акмолинской области за 2019-2020 гг., структура действующих малых и средних субъектов агробизнеса, экспорта и импорта в торговле со всеми государствами. На основе анализа отмечен устойчивый рост в сфере агропромышленного производства Акмолинского региона. Пандемия по-разному повлияла на различные отрасли экономики. В отношении продуктов питания - товаров первой необходимости такие жесткие ограничения не введены. По данным статистики, за шесть месяцев 2021 г. объемы продукции сельского хозяйства выросли на 2,4\% по сравнению с аналогичным периодом прошлого года. Выводы - в результате проведенных исследований определено, что в Акмолинской области рост предприятий АПК составил около 13\%. Это - самый высокий показатель за последние 10 лет. Агропромышленный комплекс в условиях кризиса стал основным фактором, сдерживающим инфляцию.

Key words: agricultural sector, pandemic, animal husbandry, food security, foreign trade, government support, small and medium business, loans, export.

Түйінді сөздер: аграрлық сектор, пандемия, мал шаруашылығы, азық-түлік қауіпсіздігі, сыртқы сауда, мемлекеттік қолдау, шағын, орта бизнес, несиелер, экспорт.

Ключевые слова: аграрный сектор, пандемия, животноводство, продовольственная безопасность, внешняя торговля, государственная поддержка, малый, средний бизнес, кредиты, экспорт.

Introduction. When coronavirus pandemic came to Kazakhstan, food security and agricultural development were the most important problems. Now many countries are concentrated on ensuring the domestic market and import substitution through the development of the agrarian sector [1].

The risks associated with food security are minimal for our country. Kazakhstan almost completely provides itself with the 
main types of food products. There are partial imports of poultry meat, finished dairy products, fruits, sugar, but its share is decreasing every year, many new domestic industries are being created [2]. In 2019 alone, Kaz Agro Holding implemented 84 projects totaling 102 billion tenge at the expense of financing.

The coronavirus pandemic has affected different sectors of the economy in different ways. The areas where consumers access to services and goods is restricted caused the greatest damage. We see that services and entertainment, tourism, and trade in non-food products have suffered greatly. No such strict restrictions have been imposed on food essential goods.

Akmola region is the of the most agricultural regions of the republic which are producing $6 \%$ of meat, $23 \%$ of grain and $7 \%$ of milk. Over the past 3 years, the average annual grain production in the region amounted to 4.7 million tons, and the average annual grain export for the same period amounted to 1.6 million tons [3].

Material and methods of research. The theoretical and methodological basis of the research is based on the scientific works of domestic and foreign scientists-economists on the dynamics of agricultural entrepreneurship development in the context of the pandemic, the Resolutions of the Government of the Republic of Kazakhstan, legislative acts.

During the study, various research methods were used, depending on the purpose and objectives of the study: abstract-logical-to study the directions of development of economic indicators of agricultural enterprises; monographic-to study the experience of agricultural entrepreneurs from near and far abroad in the context of the pandemic; analysis of the current state of agricultural entrepreneurship in the Akmola region.

The data of the Committee on Statistics of the Ministry of National Economy of the Republic of Kazakhstan, the Ministry of Agriculture, reporting documents of agricultural enterprises, statistical data of research institutions were used as the information base of the study. In connection with the research topic, domestic and foreign publications, materials of scientific-theoretical, scientific-practical conferences, materials of mass media, articles from periodicals were used.

Results and their discussion. By the data of the Statistics Committe of the Ministry of National Economy of the Republic of Kazakhstan, the gross of the regional product of the Akmola region is estimated at 0.8 trillion tenge, which provided the region with a share in the gross domestic product of $2.9 \%$, which is $2.5 \%$ higher than in the first half of 2019.

By results of the first quarter of 2020, in terms of the share of small and medium-sized businesses in the gross regional product, Akmola region took the 9th place $(24.8 \%)$. At the same time, compared to 2019 , there is a tendency for this indicator to grow by 3.4 percentage points, see figure 1 .

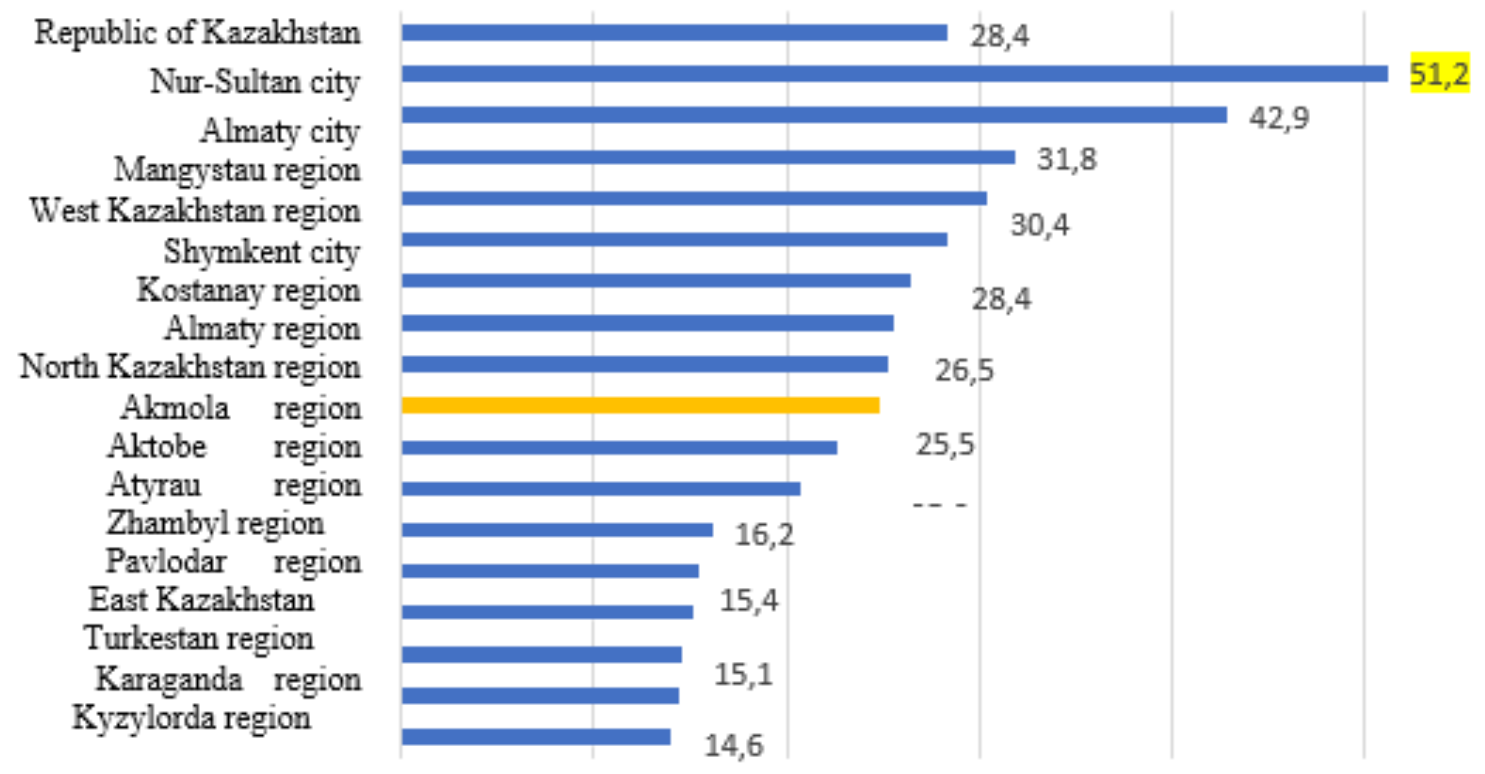

Figure 1 - The position of the Akmola region in the indicator "the share of gross value added of small and medium-sized enterprises in the GRP of the regions of Kazakhstan" for January-June 2020, \% 
Over the past three years, the region has seen a steady trend towards a stable crop yield [4]. In the development of the agroindustrial complex, special attention is paid to the introduction of modern scientific developments into production, which, is in turn, has a positive effect on the rate of increase in volumes, improving the quality and profitability of agricultural products.

In January-June 2020, the number of operating small and medium-sized businesses in the Akmola region amounted to 45.5 thousand units, or $96.0 \%$ compared to the corresponding period in 2019 (in 2019 - 47.4 thousand units), see figure 2 .

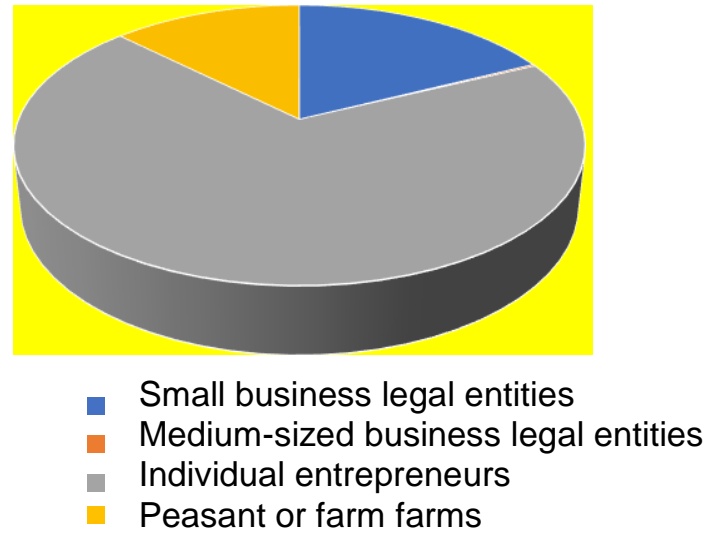

Figure 2 - Structure of operating small and medium - sized businesses in the Akmola region as of July 1, 2020, \%

The share of small and medium-sized businesses in the total volume of employment is $32.5 \%$, which is equal to 129.1 thousand people. Legal entities of small and mediumsized businesses employed 64.5 thousand people, which is $50.0 \%$ of the number of employees in small and medium-sized businesses in the Akmola region (small businesses-37.0\% and medium-sized businesses-13.0\%). Individual entrepreneurs employ $42.5 \%$ or 55.4 thousand people. Peasant (farm) farms employ $7.1 \%$ or 9.2 thousand people, see figure 3 .

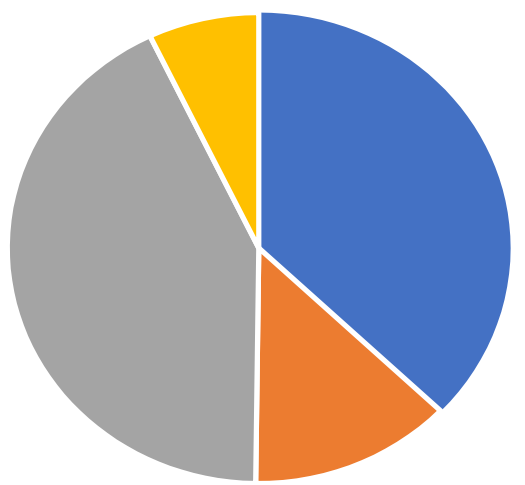

Small business legal entities

- Medium-sized business legal entities

- Individual entrepreneurs

Peasant or farm farms

Figure 3 - Distribution of employees in small and medium-sized businesses in the Akmola region by organizational and legal forms as of July 1, 2020, \%

In the first half of 2020, small and medium-sized businesses of the Akmola region produced products in the amount of 328.6 billion tenge, which is $9.9 \%$ more than in the first half of 2019 (in the first half of 2019-299.1 billion tenge) [5].

In January-June 2020, the export of goods of the Akmola region amounted to 125.4 million US dollars, which is $8.0 \%$ lower than in JanuaryJune 2019 (in 2019-136.3 million US dollars). Imports of goods from January to June 2020 amounted to 91.1 million US dollars, which is $24.3 \%$ lower than in the same period in 2019 (in 2019-120.3 million US dollars), see table.

As we see the price fluctuations, the state has the tools and resources to maintain them [6]. In order to prevent the occurrence of shortages and unjustified price increases, especially for socially important food products, in each region there are stabilization funds that purchase and sell food products. 
Table - Structure of trade in exports and imports of the Akmola region in trade with all countries in January-June of the 2020 year

\begin{tabular}{|l|r|r|r|r|}
\hline \multicolumn{1}{|c|}{$\begin{array}{c}\text { Product } \\
\text { nomenclature }\end{array}$} & \multicolumn{1}{|c|}{$\begin{array}{c}\text { Exports, } \\
\text { thousand } \\
\text { US dollars }\end{array}$} & $\begin{array}{c}\text { Total } \\
\text { share of } \\
\text { exports }\end{array}$ & $\begin{array}{c}\text { Imports, } \\
\text { thousand } \\
\text { US dollars }\end{array}$ & $\begin{array}{c}\text { Total } \\
\text { share } \\
\text { of imports }\end{array}$ \\
\hline $\begin{array}{l}\text { Animal and plant products ready-made food } \\
\text { products }\end{array}$ & 117737.35 & 93.9 & 8534.32 & 9.4 \\
\hline Mineral products, including inside: & 5259.16 & 4.2 & 1060.36 & 1.2 \\
\hline Fuel and energy goods & 4285.52 & 3.4 & 1020.39 & 1.1 \\
\hline $\begin{array}{l}\text { Products of chemical and related industries } \\
\text { (including rubber and plastics when) }\end{array}$ & 143.84 & 0.1 & 28732.63 & 31.5 \\
\hline $\begin{array}{l}\text { Leather raw materials, smears and made from } \\
\text { them products }\end{array}$ & 0.0 & 0.0 & 2.48 & 0.0 \\
\hline Wood, forest materials paper and pulp products & 0.0 & 0.0 & 377.63 & 0.4 \\
\hline \multicolumn{1}{|c|}{ Noteased } & & & & \\
\hline
\end{tabular}

Note-based on Statistics Committee of the Ministry of national economy of the Republic of Kazakhstan, 2020.

In 2020, JSC "Agrarian Credit Corporation" allocated a budget loan in the amount of 70 billion tenge to finance the sowing and harvesting campaign. Akmola region is one of the most dynamically developing regions of the country. Special attention in the region is paid to cattle breeding, combined with agriculture [7]. Due to the state support in the region, the number of livestock increases every year. This industry is developing in the meat and dairy sectors. Last year, 150 meat processing farms were opened, 10 thousand heads of breeding cattle were purchased.

Also there has been opened four dairy farms. Nevertheless, all the success works of the region is not only this, its also in the fact that now local specialists intend to meet the demand in the domestic market and increase the export potential of the region. For that, in 2022, the task is to increase the production of meat to 120 thousand tones, milk-to 200 thousand tons. In addition, it is planned to open a feedlot for 7 thousand heads of cattle and 135 meat processing farms in the districts. One of them is in the Arshalyn district for 7 thousand heads of cattle (Aizet farms LLP), in the city of Kushetau for 5 thousan d, heads of cattle ("Bibord" LLP) and Tselinograd district ("Agropark" LLP). The region also pays attention to the development of dairy cattle breeding. This year, will begin the construction of 9 dairy farms for 4.600 cows. Also, hree large farms are planned in Akkol, Astrakhan and Atbasar districts.

Akmola region is one of the leading agricultural regions of Kazakhstan. Every year, the Akmola region produces a third of the republican gross harvest of high-quality grain and is an important link in this area.

Ensuring the food security of the country and creating the food belt of the city of NurSultan [8]. As part of the diversification of agricultural production, there is a significant increase in oilseeds, fodder and legumes, potatoes and vegetables. Along with the export of wheat flour and grain, oilseeds, vegetable oil, animal products - meat and sausage products-are supplied to foreign markets.

The strategic objective of the development of agriculture in the Akmola region is to preserve and increase soil fertility, control erosion processes, diversify and optimize the structure of acreage with an increase in the share of oilseeds and oilseeds, the entire food production chain is classified as "essential" goods during the Covid-19 quarantine, so the agricultural industry continues to operate smoothly.

In 2020, steady growth is observed in the field of agriculture of the Akmola region. The figure is about 13 percent. This is the highest indicator in the industry in the last 10 years. The agro-industrial complex in the conditions of the crisis has become the main factor in restraining inflation in the region [9].

The largest projects are the modernization of the largest dairy processing enterprise in our region-Gormolzavod LLP. The total capacity is 150 tons per day. Also, the creation of a feed mill with a capacity of 28 thousand tons per year-MMK Ayan LLP in the Arshalyn district.

In the Birzhan Sal district, the construction of a breeding reproducer for four and a half thousand heads of cattle-Burabay Astyq LLP-has been completed. In the city of Kokshetau, the construction of a feedlot of "Bibord"LLP with a capacity of five thousand heads has been completed. The second stage of the Makinskaya Poultry Farm has been launched. After the expansion, the poultry farm became a large enterprise in terms of chicken meat production [10]. 


\section{Conclusions}

According to the results of the study, the introduction of new technologies after the pandemic may be accelerated not because of the situation in the domestic market, but because of the need to compete with manufacturers of developed countries engaged in automation in global markets. In addition, the objectives of the «National Development Plan» includes increasing agricultural investment in irrigation, increasing productivity and expanding export markets. Such goals may promote (or require) more active automation. It is necessary to conduct an in-depth scientific study of the situation in the field of agricultural entrepreneurship.

Conducting comprehensive diagnostics of agricultural land, inventory of resourcespersonnel, wells and wells, equipment, storage, and marketing infrastructure.

Completely revise the methodology of statistical reporting. The program must be based on reliable data. Such research should be regular and publicly funded.

Education of the agricultural manager - is one of the most important factors of competitiveness and survival of agriculture. Regular refresher courses for rural professionals and farmers are needed at institutes and colleges. The provision of subsidies related to the level of qualification of farmers, their involvement of specialists, their constant training, will serve as a qualitative activation in the field of personnel training. During the post-Covid-19 economic recovery, authorities and businesses in all countries with large-scale agriculture should pay more attention to automation trends.

\section{References}

[1] В условиях пандемии в РК увеличены посевные площади сельхозкультур [Электронный ресурc].- 2021.- URL: https://www.inform.kz/ ru/ v-usloviyah-pandemii-v-rk-uveli-cheny-posevnye-ploschadi-sel-hozkul-tur_a3737824 (дата обращения: 06.02.2021).

[2] Статистический сборник «Сельское, лесное и рыбное хозяйство в Республике Казахстан». Комитет по статистике МНЭ РК [Электронный ресурc].-2021.-URL:https://www. stat.gov.kz/ (дата обращения: 09.02. 2021).

[3] Государственная программа развития продуктивной занятости и массового предпринимательства на 2017-2021 годы «Еңбек». - Астана: РГП на правах ПХВ «Институт законодательства и правовой информации Республики Казахстан» Министерства юстиции Республики Казахстан, 2017.- 117 с.

[4] Анализ рынка сельского хозяйства в Казахстане: валовый продукт, занятость на- селения, производственные системы, госпрограмма развития АПК, сельскохозяйственные организации [Электронный ресурс]. -2021. - URL: https: //www. marketingcenter.kz/ (дата обращения: 20.01.2021).

[5] Молдашев, А.Б. Проблемы устойчивого функкционирования продовольственной системы Республики Казахстан / А.Б. Молдашев, Г.А. Никитина // Проблемы агрорынка. -2019.- №2. - C.11-19.

[6] Аленова, К.Т. Управление сельхозпредприятием на примере АO "Агрофирма" Актык "в Акмолинской области Казахстана / К.Т. Аленова, Б.С. Утибаев // Проблемы агрорынка. - 2020. - №2. - С.112-118.

[7] Офрициальный сайт Министерства индустрии и инфраструктурного развития Республики Казахстан [Электронный ресурс]. 2021.- URL: https://www.gov.kz/memleket/ entities/miid?lang=ru (дата обращения: 10.01.2021).

[8] Послание Главы государства КасымЖомарта Токаева народу Казахстана. 1 сентября 2020г. [Электронный ресурс]. - 2021. URL: https://www.akorda.kz/ru/ addresses/addresses_of_president/ poslanie-glavy-gosudarstva-kasym-zhomarta-tokaeva-narodu-kazahstana -1-sentyabrya-2020-g (дата обращения: 11.12. 2020).

[9] 10 рациональных шагов для развития бизнеса [Электронный ресурс]. -2021. - URL: https://atameken.kz/kk/projects/24001-0-shagovpo-razvitiyu-predprinimatel-stva/ (дата обращения: 12.02.2021).

[10] Смагулова, Ш.А. Рекомендации по совершенствованию реализации устойчивого развития АПК Казахстана / Ш.А. Смагулова, Г.Ж. Доскеева.- Алматы: TSTCompany, 2016.- 48 с.

\section{References}

[1] «V usloviyah pandemii v RK uvelicheny posevnye ploshchadi sel'hozkul'tur» [In the context of a pandemic in the Republic of Kazakhstan, the sown areas of agricultural crops has been increased]. - 2021 - Available at: https:// www.inform.kz/ru/v-usloviyah-pandemii-v-rk-uvelicheny-posevnye-ploschadi-sel-hozkul-tur_a373 7824/ (date of access: 06.02.2021) [in Russian].

[2] Statisticheskij sbornik «Sel'skoe, lesnoe i rybnoe hozyajstvo v Respublike Kazahstan». Komitet po statistike MNE RK [Committee on Statistics of MNE RK]. 2021 - Available at: https: //www. stat.gov.kz (date of access: 09.02.2021) [in Russian].

[3] Gosudarstvennaya programma razvitiya produktivnoj zanyatosti i massovogo predprinimatel'stva na 2017-2021 gody «Eңbek» [Enbek state program for the development of productive employment and mass entrepre-neurship for 2017-2021]. Astana: RGP na pravah PHV «Institut zakonodatel'stva i pravovoj informacii Respubliki Kazahstan» Ministerstva justicii Respubliki Kazahstan (2017), 117 p [in Russian]. 
[4] Analiz rynka sel'skogo hozyajstva $v$ Kazahstane: valovyj produkt, zanyatost' naseleniya, proizvodstvennye sistemy, gosprogramma razvitiya APK, sel'skohozyajstvennye organizacii [Analysis of the agricultural market in Kazakhstan: raw products, employment of the population, production systems, state program for the development of agriculture, agricultural organizations]. - 2021 - Available at: https: //www. marketingcenter.kz / (date of access: 20.01.2021) [in Russian].

[5] Moldashev, A.B. \& Nikitina, G.A. (2019). Problemy ustojchivogo funkcionirovaniya prodovol'stvennoj sistemy Respubliki Kazahstan [Problems of sustainable functioning of the food system of the Republic of Kazakhstan]. Probemy agrorynka - Problems of AgriMarket, 2, 1119 [in Russian].

[6] Alenova, K.T. \& Utibaev, B.S. (2020). Upravlenie sel'hozpredpriyatiem na primere $A O$ "Agrofirma "Aktyk"» v Akmolinskoj oblasti Kazahstana [Agricultural enterprise management based on the example of "Agrofirm "Aktyk"» JSC in Akmola region of Kazakhstan]. Problemy agrorynka - Problems of AgriMarket, 2, 112-118 [In Russian].

[7] Oficial'nyj sajt Ministerstva industrii i infrastrukturnogo razvitiya Respubliki Kazahstan
[Official website of the Ministry of Industry and Infrastructure Development of the Republic of Kazakhstan]. - 2021 - Available at: https: //www.gov.kz/memleket/entities/miid?lang=ru / (date of access: 10.01.2021) [in Russian].

[8] Poslanie Glavy gosudarstva KasymZhomarta Tokaeva narodu Kazahstana. 1 sentyabrya $2020 \mathrm{~g}$. [Message from the Head of State Kassym-Zhomart Tokayev to the people of Kazakhstan. September 1, 2020]. - 2021 - Available at: https://www.akorda.kz/ru/addresses/ addresses_of_president/poslanie-glavy-gosudar stva-kasym-zhomarta-tokaeva-narodu-kazahstana-1-sentyabrya-2020-g/ (date of access: 11.12.2020) [in Russian].

[9] 10 racional'nyh shagov dlya razvitiya biznesa [10 Rational Steps for Business Development]. - 2021 - Available at: https: // atameken.kz/ kk/ projects/ 24001-0-shagov-porazvitiyu-predprinimatel-stva/ (date of access: 12.02.2021). [in Russian].

[10] Smagulova, Sh.A.(2016). Rekomendacii po sovershenstvovaniju realizacii ustojchivogo razvitija APK Kazahstana [Recommendations on improving the implementation of the sustainable development of the agro-industrial complex of Kazakhstan]. Almaty: TSTCompany, 48 p. [in Russian].

\section{Information about authors:}

Kuandykova Marzhan Bolatbekovna - The main author; Ph.D student; "Turan" University; 050013 Satbayev str., 16a, Almaty, Kazakhstan; e-mail: marchan1402@mail.ru; https://orcid.org/0000-00025804-7691

Omarbakiyev Lutpulla Amurullamovich; Doctor of Economic Sciences, Professor; Professor of Department of Finance; "Turan" University; 050013 Satbayev str., 16a, Almaty, Kazakhstan; e-mail: omarbakiyev@mail.ru; https://orcid.org/0000-0002-3474-6244?lang=en

Kamysbayev Marat; Doctor of Economic Sciences, Professor; Professor of Department of Economics and Business; International University of Information Technologies; 050040 Manasa str., 34/1, Almaty, Kazakhstan; e-mail: marat.kamysbayev@gmail.com; https://orcid.org/0000-0002-6592-6030

\section{Авторлар туралы ақпарат:}

Қуандықова Маржан Болатбековна - негізгі автор; Ph.D докторанты; «Туран» университеті; 050013 Сатпаева көш., 16a, Алматы қ., Қазақстан; e-mail: marchan1402@mail.ru; https://orcid.org/0000-0002-5804-7691

Омарбакиев Лутпулла Амурулламович; экономика ғылымдарының докторы, профессор; «Қаржы» кафредрасының профрессоры; «Туран» университеті; 050013 Сатпаева көш., 16а, Алматы қ., Қазақстан; e-mail: omarbakiyev@mail.ru; https://orcid.org/0000-0002-3474-6244?lang=en

Камысбаев Mарат; экономика ғылымдарының докторы, профессор; «Экономика және бизнес» кафедрасының профессоры; Халықаралық ақпараттық технологиялар университеті; 050040 Манас көш., 34/1, Алматы қ., Қазақстан; e-mail: marat.kamysbayev@gmail.com; https://orcid.org/00000002-6592-6030

\section{Информация об авторах:}

Куандыкова Маржан Болатбековна - основной автор; докторант Ph.D; Университет «Туран»; 050013 ул. Сатпаева, 16а, г.Алматы, Казахстан; e-mail: marchan1402@mail.ru; https://orcid.org/00000002-5804-7691

Омарбакиев Лутпулла Амурулламович; доктор экономических наук, профессор; профессор кафедры «Финансы»; Университет "Туран"; 050013 ул. Сатпаева, 16а, г.Алматы, Казахстан; e-mail: omarbakiyev@mail.ru; https://orcid.org/0000-0002-3474-6244?lang=en

Камысбаев Марат Куралбекович; доктор экономических наук, профессор; профессор кафедры «Экономики и бизнеса»; Международный университет информационных технологий; 050041 ул. Манаса, 34/1, г. Алматы, Казахстан; e-mail: marat.kamysbayev@gmail.com; https://orcid.org/00000002-6592-6030 